those bloods in which the disease is chronic, the count high and the patient relatively comfortable, one finds that adult leucocytes with their mothor cells make up the bulk of the increase. As the count falls the cells develop an increasingly immature complexion. The fall chiefly affects the adult fully-differentiated sterile cells, more and more of the mother cells (myelocytes) enter the blood, and are later accompanied by cells so far back in the ancestry of the hæmal leucocyte that they bear no distinguishing mark or characteristic by which one can easily relate them with any cell found in normal blood. It is around these cells that the battles in the hæmatological world are waged most fiercely, but whatever their embryological relations may be, there is no doubt that in the majority of cases their progressive increase in numbers, even with a numerically normal blood-count, is of serious prognostic significance. These cells are usually the parent cells of the granular myelocytes of the bone-marrow. Superficially they closely resemble the large mononuclear leucocyte of normal blood, are devoid of stainable granules, and do not possess to any degree the hall mark which distinguishes cells of bone-marrow origin, namely, a cytoplasmic oxydase capable of being demonstrated by the indo-phenol reaction. Their superficial resemblance to lymphocytes, and the fact that so many cases of chronic leucosis have an acute termination in which these cells outnumber all other forms of leucocyte, gave rise to the erroneous impression that cases of "chronic myeloid leukamia," leucosis of the myeloid type, could terminate as "acute lymphatic leukæmia," leucosis of the lymphatic type.

Now acute leucosis of the lymphatic type is a very rare disease, much less common than acute myeloid leucosis, and an acute termination is frequent in the relatively common chronic myelosis, so that whenever these primitive cells are encountered in large numbers in blood-films, it is likely that they are the parent cells of myelocytes and are properly called myeloblasts. A high percentage of myeloblasts therefore indicates a case of chronic myelosis approaching the end, or one in which the count has been modified by treatment or myelosis in a dangerously acute form.

To summarize, one may state that :-

(I) A total leucocyte count falling within the limits of normal may be found in the "leukæmias" (leucoses).

(2) If occurring spontaneously, it is usually of serious import.

(3) Accompanying the fall there is usually a gross increase in the percentage of large, relatively simple cells resembling the large mononuclear leucocyte of normal blood.

(4) In the large majority of cases these cells are myeloblasts.

\section{LONDON SCHOOL OF HYGIENE AND TROPICAL MEDICINE.}

\section{(UNIVERSITY OF LONDON.)}

Ar the Annual Meeting of the Court of Governors of the London School of Hygiene and Tropical Medicine, held on November 30, in the Council Room of the British Medical Association's house in Tavistock Square, the Board of Management of the School presented their Fourth Annual Report. Sir Holburt Waring was in the chair. The Board state that substantial progress has been made towards the completion of the organization of the School, of the building, and of its equipment.

The work of the old School of Tropical Medicine, which was taken over in 1924, continues to make most satisfactory progress, and the Director reports that there is an increase of no less than 17 per cent. in the proportion of students sitting for the Diploma in Tropical Medicine and Hygiene who were successful. 
Advanced courses in Bacteriology have been established in temporary quarters in Gordon Square, and all of the five students who sat for the new University Diploma were successful in obtaining it. Special courses in Epidemiology and Vital Statistics have also been established.

The Professors of Public Health, of BioChemistry, and of Chemistry as applied to Hygiene have been appointed, and will enter upon their duties next year.

It is hoped that the very handsome building in Portland stone, which is being completed in Bloomsbury to the design of Mr. Morley Horder and Mr. Verner O. Rees, will be ready for the formal opening next summer.

\section{$\ldots$ \\ EDITORIAL NOTES.}

The fai-flung tentacles of the Fellowship of Medicine appear to have embraced some of the lesser-known portions of the Empire. We reproduce two letters received from West Africa. From their tenor, we doubt if the facilities of the Fellowship of Medicine will enable the writers to satisfy examining boards in this country, but it is stimulating to have definite proof that our efforts to assist in post-graduate work are becoming recognized, even though the requests in these letters would appear to suggest needs which the Fellowship of Medicine, reluctantly and with all humility, cannot serve.

\section{Love Abraham Braide Esq \\ Bakana christ army Church Iron hall P.O. box 20 Port harcourt W.C. Afirica}

\section{Dear Sir}

I have the honour most respect full to apply for your fully illustrated catalogue of I928 and 1929 Also your full range of Samples of all kinds for I Wish to be your Sole agent in Nigeria and As Such wishing to know What Will be me amount to deposit you in bank so as to Start the business Awaiting to you as quick as possible

I remain yrs in haste

Love Abraham Braide Esq

Sokari O. Patrick

Crystal up Stair

Bakana

P. o. Box 20

Via P. Harcourt

Dear Sir,

With much adequate conception and in a lovelihood. I do beg to apply for a fully illustrated catalogue of years to which I think a grant is available cantion me to cease that motion of my pen and please debar it. Trusting to hear from you in the course of a few days

$$
\begin{aligned}
& \text { The macidonian } \\
& \text { Prim rose } \\
& \text { I remian yrs } \\
& \text { Faithfully } \\
& \text { Sokari O. Patrick } \\
& \text { Crystal up Stair }
\end{aligned}
$$

\section{POST-GRADUATE NEWS.}

By reason of the Christmas vacation it is not practicable to arrange for many Special Courses in January. There are, however, four in number, namely, an intensive course in medicine, surgery, and the specialities at the North-East London Post Graduate College (Prince of Wales's General Hospital), Tottenham, N.15. This is a particularly comprehensive course-the daily sessions begin at ro.30 a.m. and end at about 5.30 p.m. Clinical and laboratory methods, \&c., are dealt with, demonstrations given on selected cases, and formal clinical lectures at 4.30 p.m., to which members of the Fellowship of Medicine are invited. The fee for the course is $655 \mathrm{~s}$., and the dates January 28 to February 9 .

The second course is that in Cardiology, arranged to take place at the National Hospital for Diseases of the Heart, January I4 to 26. By reason of the popularity of 